\title{
Chronic marginal stress and periodontitis
}

\author{
Stresul şi parodontita marginală cronică
}

\author{
Radu Costea ${ }^{1}$, Alexandra Totan², Daniela Miricescu², Maria Greabu' ${ }^{2}$, Cristian Scheau ${ }^{3}$, \\ Andreea Didilescu ${ }^{1}$ \\ ${ }^{1}$ Disciplina Embriologie, Facultatea de Medicină Dentară, UMF „Carol Davila“, Bucureşti, România \\ 2Disciplina Biochimie, Facultatea de Medicină Dentară, UMF „Carol Davila“, Bucureşti, România \\ ${ }^{3}$ Disciplina Fiziologie I, Facultatea de Medicină, UMF „Carol Davila“, Bucureşti, România
}

\begin{abstract}
Objectives. The aim of our study was to evaluate salivary cortisol levels and the scores of nicotinic social dependence, as markers of stress, in a group of patients with moderate and profound chronic periodontitis but systemically healthy. Material and method. Our study, of pretreatment cross-sectional design, included 28 adult patients with moderate and severe chronic marginal periodontitis and no systemic diseases. They were recruited from a particular clinic in Bucharest. The questionnaire used gathered questions from the Kano test to assess nicotine dependence. The salivary cortisol was determined using a DSNOV20 kit (NovaTec Immundiagnostica GmbH).

Results and discussions. The average Kano total score was $13.28(+4.38$; range $4-23)$. The smoker group recorded an average of 16.2 (range 11-23). There were no statistically significant differences between the scores of the three groups. From the 28 patients who completed the questionnaires, 22 were evaluated for salivary cortisol levels. Of these, 3 were smokers, 6 were former smokers and 13 were non-smokers. The mean salivary cortisol level was 6.65 $\mathrm{ng} / \mathrm{ml}$ (+ 1.47; range 4.12-9.38). The mean salivary cortisol level was higher in smokers compared to non-smokers and ex-smokers $(p>0.05)$.

Conclusions. Stress, expressed by the average level of salivary cortisol, was higher among smokers compared to the other groups, the highest variability being registered among ex-smokers. In patients with moderate and severe chronic marginal periodontitis, there was a positive, albeit insignificant, association between salivary cortisol levels and nicotinic psychological dependence.
\end{abstract}

Keywords: cortisol, nicotinic social dependence, chronic marginal periodontitis

\section{REZUMAT}

Obiective. Evaluarea nivelurilor de cortizol salivar și a scorurilor de dependență socială nicotinică ca markeri ai stresului, într-un grup de pacienți cu parodontite marginale cronice moderate și profunde, sănătoși sistemic.

Material şi metodă. Studiul, de design transversal pretratament, a cuprins un număr de 28 pacienți adulți cu parodontită marginală cronică moderată și severă și fără boli sistemice, recrutați de la o clinică particulară din București. Chestionarul folosit a reunit întrebări ale testului Kano, pentru evaluarea dependenţei sociale nicotinice. Determinarea cortizolului salivar s-a făcut folosind un kit DSNOV20 (NovaTec Immundiagnostica GmbH).

Rezultate şi discuţii. Media scorului total Kano a fost de 13,28 (+ 4,38; interval 4-23). Grupul fumătorilor a înregistrat o medie de 16,2 (interval 11-23). Nu s-au înregistrat diferențe statistic semnificative între scorurile celor trei grupuri. Dintre cei 28 de pacienti care au completat chestionarele, 22 au fost evaluati pentru nivelurile de cortizol salivar. Dintre aceștia, 3 au fost fumători, 6 foști fumători și 13 nefumători. Nivelul mediu al cortizolului salivar a fost de $6,65 \mathrm{ng} / \mathrm{ml}$ (+ 1,47; interval 4,12-9,38). Nivelul mediu al cortizolului salivar a fost mai crescut la fumători comparativ cu nefumători și ex-fumători ( $p>0,05)$.

Concluzii. Stresul, exprimat prin nivelul mediu al cortizolului salivar, a fost mai mare în rândul fumătorilor comparativ cu celelalte grupe, variabilitatea cea mai crescută înregistrăndu-se în rândul ex-fumătorilor. La pacienții cu parodontită marginală cronică moderată și severă, a existat o asociere pozitivă, deși nesemnificativă, între nivelurile cortizolului salivar și dependența psihologică nicotinică.

Cuvinte cheie: cortizol, dependență socială nicotinică, parodontită marginală cronică

\section{INTRODUCERE}

Printre factorii care influenţează parodontita marginală cronică, stresul cronic, depresia şi anxietatea pot avea impact negativ asupra evoluţiei bolii (1-3). Stresul cronic este un factor de risc recunos- cut, probabil din cauza stimulării axului hipotalamo-hipofizo-suprarenalian (4).

Cortizolul, supranumit hormonul stresului, este cel mai răspândit biomarker folosit în studiile de evaluare a stresului. Saliva este curent folosită ca instrument de diagnostic pentru boli orale şi siste- 
mice, datorită avantajelor pe care le prezintă: este uşor de colectat prin tehnică noninvazivă, care nu necesită un echipament special (5).

Modelele teoretice au subliniat rolul stresului în vulnerabilitatea la dependenţă (6). Se ştie că stresul perceput mai puternic contribuie la riscul fumatului, de la iniţiere şi până la recădere după abandon (7). Circuitele nervoase implicate în reglarea stresului sunt activate în timpul consumului acut de nicotină, sugerând că anumite aspecte ale răspunsului biologic ar putea accentua reacţia la stres şi la nicotină. Alterările răspunsurilor sistemului nervos simpatic şi axului hipotalamo-hipofizo-suprarenalian au fost, de asemenea, legate de dependenţa nicotinică (8).

$\mathrm{Cu}$ toate că studii anterioare au investigat impactul componentelor psihosociale asupra extinderii şi severităţii bolii parodontale, puţine studii au evaluat impactul relaţiei dintre dependenţa socială nicotinică, statusul sistemului imun şi sănătatea parodontală. Am pornit de la ipoteza că, în condiţiile unui grad ridicat de dependenţă socială nicotinică, se produce hiperactivarea axului hipotalamo-hipofizo-suprarenalian, cu afectare parodontală.

\section{OBIECTIV}

Obiectivul studiului a fost de a evalua nivelurile de cortizol salivar şi scorurile de dependenţă socială nicotinică ca markeri ai stresului, într-un grup de pacienţi cu parodontite marginale cronice moderate şi profunde, sănătoşi sistemic.

\section{MATERIAL ŞI METODE}

Acest studiu a avut un design transversal pretratament. 28 de pacienţi adulţi cu parodontită marginală cronică moderată şi severă şi fără boli sistemice au fost recrutaţi de la o clinică particulară din Bucureşti. Examinările parodontale la nivelul întregii cavităţi bucale au fost realizate de un medic instruit în acest sens (RC). Chestionarele au fost completate în cursul perioadei 2015-2017. Participarea în studiu s-a făcut pe baza consimţământului liber informat.

Chestionarul folosit a cuprins întrebări ale testului Kano pentru evaluarea dependenţei sociale nicotinice (9). Datele despre dependenţa nicotinică socială au fost colectate folosind versiunea 2 a tes- tului Kano, constând din 10 întrebări (Tabel 1), dintre care prima este invers punctată. Evaluările s-au făcut pe o scală Likert cu următoarele opţiuni: ,sigur da“, „probabil da“, „probabil nu“ şi „,sigur nu“. Intervalul posibil al scorurilor totale Kano se situează între 0 (indicând dependenţă nicotinică socială scăzută) şi 30 (indicând dependenţă nicotinică socială mare).

TABELUL 1. Testul Kano pentru dependența nicotinică socială (KTSND)

\begin{tabular}{|l|l|}
\hline \multicolumn{1}{|c|}{ Întrebări } & \multicolumn{1}{|c|}{ Scoruri } \\
\hline 11: Fumatul este o boală & SD (0) PD (1) PN (2) SN (3) \\
\hline I2: Fumatul este parte a culturii locale & SD (3) PD (2) PN (1) SN (0) \\
\hline $\begin{array}{l}\text { I3: Fumatul este una dintre plăcerile } \\
\text { vieții }\end{array}$ & SD (3) PD (2) PN (1) SN (0) \\
\hline $\begin{array}{l}\text { I4: Stilurile de viață ale fumătorilor } \\
\text { pot fi respectate }\end{array}$ & SD (3) PD (2) PN (1) SN (0) \\
\hline $\begin{array}{l}\text { I5: Câteodată, fumatul îmbunătățeşte } \\
\text { viața oamenilor }\end{array}$ & SD (3) PD (2) PN (1) SN (0) \\
\hline $\begin{array}{l}\text { 16: Fumatul are efecte pozitive psihice } \\
\text { sau mentale }\end{array}$ & SD (3) PD (2) PN (1) SN (0) \\
\hline $\begin{array}{l}\text { 17: Fumatul ajută la eliminarea } \\
\text { stresului }\end{array}$ & SD (3) PD (2) PN (1) SN (0) \\
\hline $\begin{array}{l}\text { 18: Fumatul creşte activitatea } \\
\text { creierului la fumători }\end{array}$ & SD (3) PD (2) PN (1) SN (0) \\
\hline $\begin{array}{l}\text { 19:Medicii exagerează efectele } \\
\text { dăunătoare ale fumatului }\end{array}$ & SD (3) PD (2) PN (1) SN (0) \\
\hline $\begin{array}{l}\text { I10:Oamenii pot fuma în locurile unde } \\
\text { există scrumiere }\end{array}$ & SD (3) PD (2) PN (1) SN (0) \\
\hline $\begin{array}{l}\text { SN: Sigur nu; PN: Probabil nu; PD: Probabil da; SD: Sigur da; } \\
\text { () = fiecare scor }\end{array}$
\end{tabular}

Evaluarea nivelurilor de cortizol salivar s-a făcut după cum urmează. Pacienţilor li s-a recomandat să colecteze saliva dimineaţa, înainte de periaj dentar, fumat, mic dejun sau consum de lichide. Saliva a fost colectată în tubi sterili, pretratament. Eşantioanele au fost menţinute la $-20^{\circ} \mathrm{C}$ înainte de procesare. Determinarea cortizolului s-a făcut folosind un kit DSNOV20 (NovaTec Immundiagnostica $\mathrm{GmbH}$ ). Metoda de determinare cantitativă folosită a fost una colorimetrică imuno-enzimatică.

\section{Analiza statistică}

Datele au fost exprimate sub formă de medii, abateri standard, mediane, intervale sau procente, după caz. Analiza posibilelor diferențe între fumători şi nefumători s-a făcut cu teste neparametrice. Testul Mann-Whitney a fost folosit pentru comparaţia scorurilor KTSND obţinute, în funcţie de statusul de fumător. Analiza datelor din eşantion s-a realizat folosind programul de statistică StataIC 14 
(StataCorp. 2015. Statistical Software. College Station, TX, USA). Valoarea $p<0,05$ a fost considerată statistic semnficativă.

\section{REZULTATE}

\section{Caracteristicile eşantionului de pacienți respondenți}

Eşantionul utilizat a fost format din 28 pacienţi cu parodontopatii marginale cronice, medie de vârstă 40,68 ani ( $\pm 9,53$; interval 26-61), care au completat chestionarele înainte de a începe tratamentul. Din totalul respondenţilor, $42,9 \%$ au fost de gen feminin ( $n=12)$. Prevalenţa fumatului în rândul pacienţilor este ilustrată în Fig. 1. Având în vedere numărul mic de fumători ocazionali $(\mathrm{n}=2)$, aceştia au fost comasaţi cu fumătorii zilnic. Niciodată fumătorii nu au fost considerați nefumători.

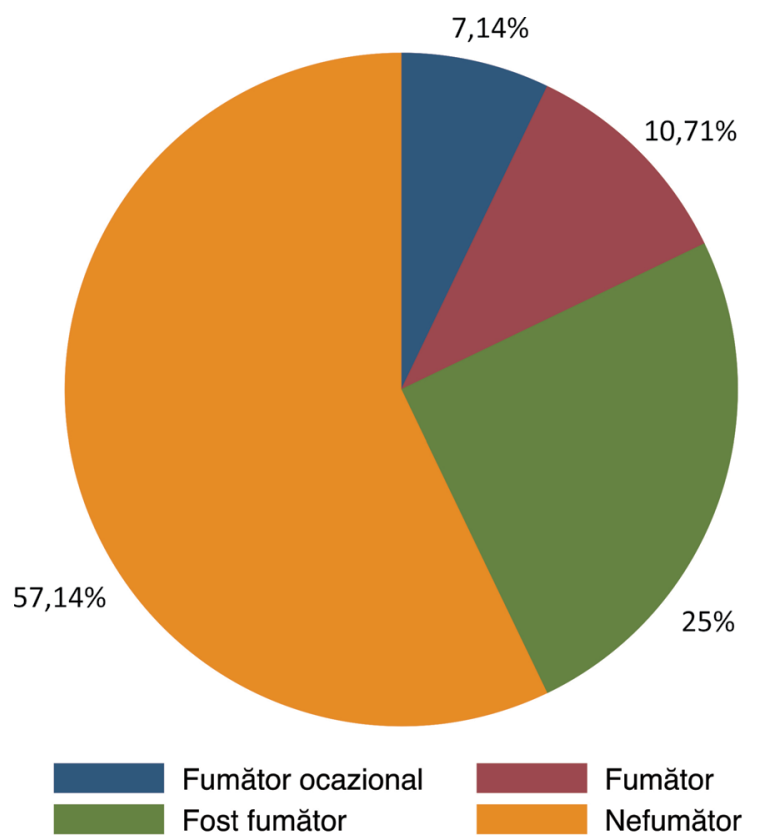

FIGURA 1. Statusul fumatului în rândul pacienților respondenți

Media vârstei de debut al fumatului a fost de 18,2 ani $(+/-2,9)$, interval 14-25 ani. În ceea ce priveşte tentativele de abandon, 91,7\% au încercat cel puţin o dată. Dintre fumătorii declaraţi, $91,7 \%$ au fumat mai multe ţigări decât au planificat pentru ziua respectivă. Pierderea autocontrolului a fost recunoscută de $50 \%$ dintre fumătorii respondenţi care au încercat să abandoneze fumatul, acelaşi procent înregistrându-se la întrebarea referitoare la continuarea fumatului în condiţiile în care respondentul era conştient că pot apărea probleme de sănătate.
Trei fumători au acuzat simptome de sevraj după abandon şi niciun fumător nu a continuat să fumeze în condiţii de boală, ştiind că fumatul poate influența negativ tratamentul. Fumătorii zilnic au recunoscut că sunt conştienţi de dependenţa de ţigări.

\section{Evaluarea dependenței nicotinice}

Media scorului total Kano a fost de 13,28 $( \pm$ 4,38; interval 4-23). Mediana a fost de 12. Grupul nefumătorilor a avut media scorurilor de 12,75 (interval 4-20), mediana 13,5; grupul ex-fumătorilor a prezentat o medie de 12,43 (interval 9-18), şi o mediană de 12. Grupul fumătorilor a înregistrat o medie de 16,2 (interval 11-23), mediana 15. Nu s-au înregistrat diferenţe statistic semnificative între scorurile celor trei grupuri.

\section{Evaluarea cortizolului salivar}

Dintre cei 28 de pacienţi care au completat chestionarele, 22 au fost evaluaţi pentru nivelurile de cortizol salivar. Vârsta medie a pacienţilor a fost de 41,59 ani (abatere standard 10,26; interval 26-61). Dintre aceştia, 3 au fost fumători, 6 foşti fumători şi 13 nefumători. 10 pacienţi au fost femei, iar 12 bărbaţi. Nivelul mediu al cortizolului salivar a fost de $6,65 \mathrm{ng} / \mathrm{ml}$ (abatere standard 1,47; interval 4,12$9,38)$. Nivelul mediu al cortizolului salivar a fost mai crescut la fumători comparativ cu nefumători şi ex-fumători $(p>0,05)$ (Fig. 2).

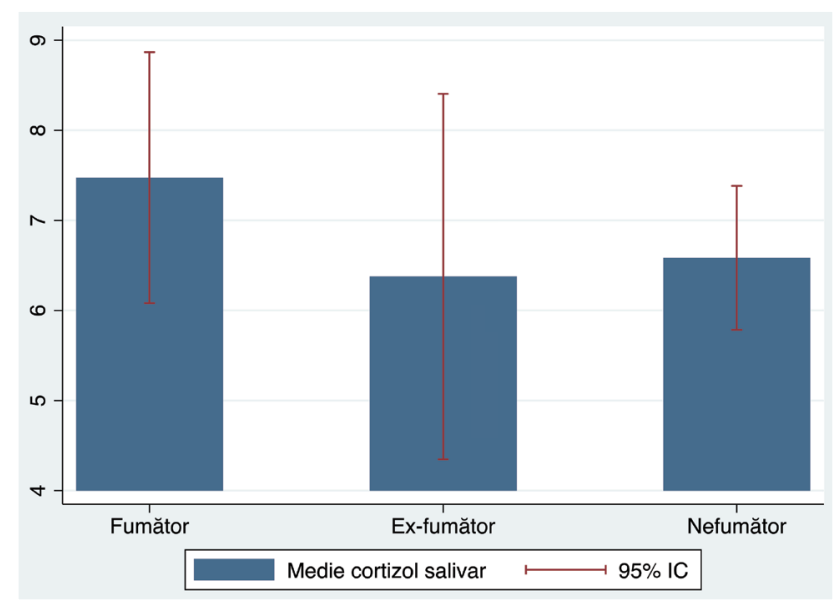

FIGURA 2. Valorile medii ale cortizolului salivar în funcție de statusul fumatului

\section{DISCUTุII}

Parodonţiul este afectat prin mai multe mecanisme, unele dintre ele neelucidate încă (10). Astfel, 
chiar în cazurile de igienă orală corespunzătoare, fumatul se poate asocia cu prevalenţă şi severitate crescute ale afecţiunilor parodontale $(11,12)$, în timp ce nicotina poate fi găsită pe suprafețele rădăcinilor dinţilor extraşi aparţinând fumătorilor (13).

Dependenţa socială nicotinică este un concept nou creat care descrie statusul psihologic şi psihosocial asociat cu fumatul, putând fi cuantificată prin folosirea testului Kano. Scorurile KTSND în studiul prezent sunt comparabile cu rezultatele anterioare obţinute în studii efectuate în şcoli dentare din Australia, Japonia şi România (14-16).

Nivelul mediu al cortizolului salivar la nivelul întregului eşantion de studiu a fost mai scăzut decât cel raportat într-un studiu precedent (17). Diferenţa rezultatelor poate fi explicată prin eşantioanele de dimensiuni mici care au fost analizate.

Asocierea dintre parodontită şi cortizol nu este încă pe deplin stabilită. O serie de studii au raportat o asociere în acest sens. Genco şi colaboratorii (18) au investigat pacienţi cu şi fără boală parodontală, observând că nivelurile de cortizol salivar bazal au fost crescute la pacienţii cu afectare parodontală; puţine detalii despre această relaţie au fost însă date. O relaţie puternică între depresia emoţională, nivelul de anxietate, nivelurile de cortizol salivar, pe de-o parte, şi parodontita marginală cronică pe de altă parte a fost demonstrată în alte studii (19-21).

Două căi leagă creierul şi sistemul imun, una dintre acestea fiind reprezentată de axul hipotalamo-hipofizo-suprarenalian (22). Axul hipotalamohipofizo-suprarenalian exercită efect inhibitor asupra răspunsului inflamator, din cauza faptului că toate componentele răspunsului imun sunt inhibate de cortizol. În timpul activării acestui ax, fenotipul T-helper al unui subiect este influenţat de inhibiţia interleukinei 12 şi stimularea interleukinei 10 de către macrofage $(4,23,24)$. Drept rezultat, ţesuturile parodontale devin mai vulnerabile la patogenii pa- rodontali în locurile cu inflamaţie parodontală, iar această situaţie poate conduce la distrucţie localizată a ţesuturilor parodontale $(4,25,26)$.

Legătura dintre atitudinile fumătorilor şi răspunsurile biologice la stresul psihosocial are la bază mecanisme diferite care au fost incriminate în funcţie de severitatea dependenţei nicotinice (27). De exemplu, fumătorii cu niveluri severe de dependenţă nicotinică au arătat răspunsuri ale cortizolului diminuate, putând beneficia de intervenţii farmacologice care stimulează reactivitatea axului hipotalamo-hipofizo-suprarenalian $(28,29)$. La polul opus, fumătorii cu dependenţă mai scăzută au prezentat niveluri de cortizol mai ridicate şi pot beneficia de intervenţii farmacologice care inhibă reactivitatea axului hipotalamo-hipofizo-suprarenalian.

În studiul prezent, a existat o asociere pozitivă între dependenţa psihologică nicotinică şi stresul salivar la pacienţii cu forme moderate şi severe de parodontită marginală cronică, fără a avea însă valori statistice semnificative. Eşantionul mic limitează generalizarea rezultatelor, iar puterea studiului a fost probabil insuficientă pentru a detecta asocieri statistic semnificative.

\section{CONCLUZII}

Testul Kano s-a dovedit a fi aplicabil în acest grup, fiind eficient în a detecta fumătorii şi nefumătorii, prin rezultatele sale. Stresul exprimat prin nivelul mediu al cortizolului salivar a fost mai mare în rândul fumătorilor comparativ cu celelalte grupe, variabilitatea cea mai crescută înregistrăndu-se în rândul ex-fumătorilor. Există o asociere pozitivă, deşi nesemnificativă, între nivelurile cortizolului salivar şi dependenţa psihologică nicotinică. Parodontita marginală cronică poate fi asociată cu modificări imunologice şi de comportament legate de psihologia pacientului.

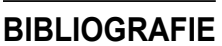

1. Mengel R, Bacher M, Flores-De-Jacoby L. Interactions between stress, interleukin-1beta, interleukin-6 and cortisol in periodontally diseased patients. Journal of clinical periodontology. 2002; 29(11):1012-22.

2. Hilgert JB, Hugo FN, Bandeira DR, Bozzetti MC. Stress, cortisol, and periodontitis in a population aged 50 years and over. Journal of dental research. 2006; 85(4):324-8.

3. Peruzzo DC, Benatti BB, Ambrosano GM, Nogueira-Filho GR, Sallum $\mathrm{EA}$, Casati $\mathrm{MZ}$ et al. A systematic review of stress and psychological factors as possible risk factors for periodontal disease. Journal of periodontology. 2007;78(8):1491-504.

4. Breivik T, Opstad PK, Gjermo P, Thrane PS. Effects of hypothalamicpituitary-adrenal axis reactivity on periodontal tissue destruction in rats. European journal of oral sciences. 2000;108(2):115-22.

5. Kaufman E, Lamster IB. The diagnostic applications of saliva - a review. Critical reviews in oral biology and medicine: An official publication of the American Association of Oral Biologists. 2002; 13(2):197-212.

6. Koob G, Kreek MJ. Stress, dysregulation of drug reward pathways, and the transition to drug dependence. The American journal of psychiatry. 2007; 164(8):1149-59. 
7. Siahpush M, Carlin JB. Financial stress, smoking cessation and relapse: Results from a prospective study of an Australian national sample. Addiction. 2006;101(1):121-7.

8. Sinha R. Chronic stress, drug use, and vulnerability to addiction. Annals of the New York Academy of Sciences. 2008;1141:105-30.

9. Yoshii C, Kano M, Isomura T, Kunitomo F, Aizawa M, Harada $\mathrm{H}$ et al. Innovative questionnaire examining psychological nicotine dependence, "The Kano Test for Social Nicotine Dependence (KTSND)". Journal of UOEH. 2006;28(1):45-55.

10. Obeid P, Bercy P. Effects of smoking on periodontal health: a review. Advances in therapy. 2000;17(5):230-7.

11. Gelskey SC. Cigarette smoking and periodontitis: methodology to assess the strength of evidence in support of a causal association. Community dentistry and oral epidemiology. 1999;27(1):16-24.

12. Kerdvongbundit $V$, Wikesjo UM. Prevalence and severity of periodontal disease at mandibular molar teeth in smokers with regular oral hygiene habits. Journal of periodontology. 2002; 73(7):735-40.

13. Cuff MJ, McQuade MJ, Scheidt MJ, Sutherland DE, Van Dyke TE. The presence of nicotine on root surfaces of periodontally diseased teeth in smokers. Journal of periodontology. 1989;60(10):564-9.

14. Didilescu A, Inagaki K, Sfeatcu R, Hanganu SC, Virtanen JI. Smoking habits and social nicotine dependence among dental students in Romania. Oral health and dental management. 2014;13(1):35-40.

15. Huang B, Inagaki K, Yoshii C, Kano M, Abbott PV, Noguchi T et al. Social nicotine dependence in Australian dental undergraduate students. International dental journal. 2011;61(3):152-6.

16. Inagaki K, Hayashi J, Ting CC, Noguchi T, Senda A, Hanamura H et al. Dental undergraduates' smoking status and social nicotine dependence in Japan and Taiwan: comparison between two dental schools. Japanese Journal of Tobacco Control. 2008;3(81-85).

17. Miricescu D, Totan A, Calenic B, Mocanu B, Greabu M. Salivary and serum cortisol in patients with periodontal disease and oral lichen planus. Stoma Edu J. 2015;1:47-51.

18. Genco RJ, Ho AW, Kopman J, Grossi SG, Dunford RG, Tedesco LA. Models to evaluate the role of stress in periodontal disease. Annals of periodontology. 1998;3(1):288-302.
19. Rosania AE, Low KG, McCormick CM, Rosania DA. Stress, depression, cortisol, and periodontal disease. Journal of periodontology. 2009; 80(2):260-6.

20. Rai B, Kaur J. Salivary stress markers and psychological stress in simulated microgravity: 21 days in 6 degrees head-down tilt. Journal of oral science. 2011;53(1):103-7.

21. Refulio Z, Rocafuerte M, de la Rosa M, Mendoza G, Chambrone L. Association among stress, salivary cortisol levels, and chronic periodontitis. Journal of periodontal \& implant science. 2013; 43(2):96-100.

22. Guyton H, Hall J. Textbook of Medical Physiology, 10 th ed. Philadelphia: W.B. Saunders Co.; 2000.

23. Pace TW, Heim CM. A short review on the psychoneuroimmunology of posttraumatic stress disorder: from risk factors to medical comorbidities. Brain, behavior, and immunity. 2011;25(1):6-13.

24. Song $\mathrm{C}$, Wang $\mathrm{H}$. Cytokines mediated inflammation and decreased neurogenesis in animal models of depression. Progress in neuropsychopharmacology \& biological psychiatry. 2011;35(3):760-8.

25. Ishisaka A, Ansai T, Soh I, Inenaga K, Yoshida A, Shigeyama C et al. Association of salivary levels of cortisol and dehydroepiandrosterone with periodontitis in older Japanese adults. Journal of periodontology. 2007;78(9):1767-73.

26. Ansai T, Soh I, Ishisaka A, Yoshida A, Awano S, Hamasaki T et al. Determination of cortisol and dehydroepiandrosterone levels in saliva for screening of periodontitis in older Japanese adults. International journal of dentistry. 2009;2009:280737.

27. Morris MC, Mielock AS, Rao U. Salivary stress biomarkers of recent nicotine use and dependence. The American journal of drug and alcohol abuse. 2016;42(6):640-8.

28. McKee SA, Potenza MN, Kober H, Sofuoglu M, Arnsten AF, Picciotto $M R$ et al. A translational investigation targeting stress-reactivity and prefrontal cognitive control with guanfacine for smoking cessation. Journal of psychopharmacology. 2015;29(3):300-11.

29. Roche DJ, Childs E, Epstein AM, King AC. Acute HPA axis response to naltrexone differs in female vs. male smokers. Psychoneuroendocrinology. 2010;35(4):596-606. 